\title{
TEATRO, PÚBLICO E ESPACIALIDADE: uma discussão do cotidiano
}

\author{
THEATRE, AUDIENCE, SPACIALITY: a daily discussion
}

\section{TEATRO, PÚBLICA Y ESPACIALIDAD: una discusión de lo cotidiano}

Shirlei Torres Perez ${ }^{1}$

\begin{abstract}
Resumo
Este trabalho busca discutir a experiência do espectador do ponto de vista da comunicação, partindo da espacialidade como mediação para a percepção de relações cotidianas, em cena e na vida corrente. Em dois espetáculos distintos - Braakland-Terra Esquecida, da Cie Dakar, da Holanda, e Os Efêmeros, do Théâtre du Soleil, da França - poética e espacialidade oportunizam diferentes construções sígnicas a partir dos deslocamentos propostos nessa relação.
\end{abstract}

Palavras-chave: Comunicação, Mediação, Performance, Teatralidade.

\begin{abstract}
This paper aims to provide a discussion about the spectator's experience, focusing the point of view of communication, bringing spatiality as mediation to the perception of relationships, on stage and in daily life. In two different plays - Braakland-Forgotten Land, of Cie Dakar, Netherlands, and The Ephemera, of Théâtre du Soleil, France - poetics and spatiality given opportunity for different semiotic constructions, from the proposed shifts in this relationship.
\end{abstract}

Keywords: Communication, Mediation, Performance, Theatricality.

\section{Resumen}

Este documento analiza la experiencia del espectador, de punto de vista de la comunicación, basado en la espacialidad como un medio para la percepción de las relaciones cotidianas, en el teatro y en la vida. En dos espetáculos - Braakland, Tierra Olvidada, de los Países Bajos y Los Efímeros, del Théâtre du Soleil, Francia - espacialidad e poética alimentan diferentes construcciones semióticas, a partir de los cambios propuestos en esta relación.

Palabras clave: Comunicación, Mediación, Performance, Teatralidad.

Umas das discussões mais instigantes acerca da relação entre o teatro e a vida corrente é a questão do público. A intersecção que se estabelece no momento da cena e os desdobramentos perceptivos, afetivos e sígnicos desse encontro. A discussão acerca

\footnotetext{
1 Mestre e Doutoranda em Comunicação e Semiótica pela Pontifícia Universidade Católica de São Paulo, em fase de pesquisa; Bacharel em Teatro pela Escola de Comunições e Artes da Universidade de São Paulo (ECA/USP), sob orientação da Profa Dra Christine Greiner.
} 
do lugar e do papel do público, passando a se constituir como elemento poético, surge como um operador complexo para novas construções e percepções, que se criam e realimentam a rede de subjetividades e significados suscitada pela performance.

Trata-se de incorporar a discussão de 'lugar' à experiência do espectador, oportunizando uma vivência política e perceptiva, mediada pelos diversos elementos da linguagem cênica. Considerar, portanto, o espetáculo do ponto de vista da comunicação, do reconhecimento sistêmico das experiências que, entendidas como sistemas sígnicos, reelaboram a relação entre objetividade e subjetividade, arte e vida, o que é e o que pode ser, e assim por diante. Ao abrir novos caminhos para a vivência do espectador, proliferam novas mediações, oportunizando possibilidades criativas de percepção.

No que se refere à discussão da linguagem teatral, a fragmentação do discurso, a diluição do texto, as redefinições das personagens, as propostas interativas e outros recursos de linguagem traduzem questões que surgem da fricção entre a ideia de teatro, sua prática e as configurações e reconfigurações das relações sociais, dos modos de produção e de partilha da informação e do conhecimento. Dessa forma, a discussão do lugar e do papel do público é constitutiva da rede de questionamentos acerca do indivíduo e de sua identidade, sua forma de vida e sua real dimensão nas redes políticas que ora se apresentam e se reconfiguram constantemente.

Os recursos técnicos que muitas vezes impressionam aos espectadores são os mesmos que estão presentes na comunicação cotidiana. Um corpo que se comunica em cena por gadgets, perplexidade e violência, faz uso estritamente de estratégias disponíveis a qualquer um, eventualmente exacerbando ou relendo seus usos e expressões. O texto fragmentado, o tempo em saltos, alargado ou diminuído, são também fenômenos correntes nas relações sociais. Toda a complexidade, ou "excentricidade", colocada em cena compartilha os mesmos recursos da vida. O indivíduo, tendo ou não domínio ou consciência disso, trabalha com essas possibilidades e circulações. As conexões são sempre possíveis; o reconhecimento e exercício dessas conexões abrem sempre mais possibilidades de percepção.

Mergulhar, portanto, na experiência do teatro, implica em relacionar-se com seu próprio contexto presente, mas implica também na relação com a memória e os rituais reconstituídos e revitalizados a cada espetáculo. Uma oportunidade de vivência ampla e diversa, que se relaciona com o cotidiano não apenas porque o traduz, ou reflete, mas porque faz parte dele, a partir de suas próprias redes de criação e circulação. 
Dessa forma, entendendo o espetáculo como um processo de comunicação, a espacialidade da cena pode ser compreendida como operadora privilegiada de mediações na relação espetáculo-espectador. Ela se configura como ação do espaço, esclarecendo que o espaço não é passivo, mas constitui-se como um sistema dinâmico. A partir das novas tessituras e construções do teatro, a espacialidade ou ação do espaço representa uma vivência que vai além da simples determinação dos espaços da sala. A espacialidade passa a ser uma negociação processual dos limites entre ator e espectador com aptidão para interferir no perfil dessa relação. A discussão do espaço incorpora as questões que se apresentam à própria natureza da performance e ao indivíduo (artista ou plateia) imerso na situação que põe à prova as questões da visibilidade do outro (sujeito ou instituições) em relação a cada um de nós.

O teatro precisa deixar de ser obra oferecida como produto coisificado (mesmo que essa obra reificada seja composta de modo processual) para assumir-se como ato e momento de uma comunicação que não só reconheça o caráter momentâneo da 'situação' teatro - portanto sua efemeridade tradicionalmente considerada como deficiência em comparação com a obra durável -, mas também o afirme como fator indispensável da prática de uma intensidade comunicativa. (LEHMANN, 2007, p. 227)

Nessa condição em que a relação se afirma como experiência, o palco deixa de ter um caráter metafórico-simbólico, em que a observação é idealmente feita de uma distância mediana. Tal distância permite uma relação de espelhamento e identificação das imagens, construções e proporções com seus equivalentes do mundo 'real' para a apreensão dos significados propostos. A espacialidade cênica pode ganhar uma dimensão metonímica, em que a parte pode ser tomada como todo, ou o todo como parte. Ficam borrados os limites entre sua dimensão real e ficcional. Esse espaço não é uma porta para um mundo fictício, mas um recorte, numa relação de contiguidade entre o mundo 'real' e o teatro. A relação com o espaço não se dá pela apreensão do que ele pode demonstrar como significado, mas pela experiência que ele media.

A metáfora, então, acontece no momento da vivência e desloca-se para o corpo. Conforme aponta Lehmann, a relação não mais acontece 'entre' os corpos. Para ele, essa relação se dá 'no' corpo, mas, pensando em termos de comunicação, de acordo com a teoria corpomídia (GREINER, 2010) esse processo é ainda mais radical, uma vez que não se dá no corpo, mas é construído pelo trânsito corpo, mente ambiente. Trata-se de um deslocamento do entendimento do espectador como receptor passivo de impressões.

Partindo dessa abordagem, apresento algumas considerações, do ponto de vista do espectador, sobre duas experiências em que a espacialidade e as imagens coti- 
dianas trazidas pelos espetáculos, conduzem a vivências distintas, que discutem as questões do indivíduo e das formas de vida, e também das formas de se relacionar com a vida. São eles: Braakland-Terra Esquecida, da Cie Dakar, da Holanda, e Os Efêmeros, do Théâtre du Soleil.

Em Braakland, o público permanece à distância. O que está em jogo é a capacidade de observação e julgamento. A estratégia é a falta de contato, a impossibilidade de interação afetiva. Sem conhecer contextos, detalhes e sentimentos envolvidos nas ações executadas por personagens distantes, que não dão pistas de motivações ou desejos, como seria possível entender, julgar e se posicionar a respeito do que se vê?

Em Os Efêmeros, trata-se da busca pela aproximação. O foco da experiência são as relações cotidianas, os sentimentos importantes, os acontecimentos marcantes da vida de pessoas comuns. São momentos efêmeros e seres efêmeros. O espectador é convidado a observar cenas intimistas, a mirar um recorte focado nas histórias pessoais e no trabalho minucioso dos atores. A peça emociona a partir da evolução das histórias e das relações através do tempo, e convida o espectador a observar, tanto para identificar-se como para distanciar-se. Ele ri e se entristece com cada cena, sem, no entanto, perder a referência do espetáculo, da maquinaria, dos recursos teatrais, do contrarregra à maquiagem.

A Cie. Dakar foi criada pelo ator e diretor Guido Kleene em 2001. O nome da Cia é o mesmo da capital do Senegal, país africano onde nasceu e onde ainda reside parte de sua família. O diretor, branco e rico, num lugar onde a realidade era em geral outra. Segundo Kleene, podendo compreender uma realidade como essa, pode-se compreender a si mesmo, inclusive pelas referências opostas, no que há de comum e de diferente.

A companhia busca conectar-se a outros artistas que, segundo o diretor, tenham algo a dizer sobre o mundo em que vivemos - o que chamam de criadores inspirados. As performances criadas pelo grupo são explícitas e diretas, escolhendo uma estética simples e limpa, refinada. Eles falam de um mundo "maior que a Holanda e menor que nós mesmos". Seu objetivo é oferecer ao público ângulos inusitados de visão. Para tanto, apresentam-se aos mais diversos tipos de plateias, principalmente aos não acostumados às linguagens experimentais.

A diretora Lotte van den Berg trabalhou a partir de improvisação, apresentando aos atores perguntas sobre seus sentimentos em relação à morte e a solidão: $O$ processo começou com idéias e perguntas pessoais. Os atores trabalharam com o paradoxo de como aceitar a morte e, ao mesmo tempo, como lutar contra ela. 
Nove personagens movem-se em um terreno amplo e deserto. Realizam ações simples, quase esquemáticas. Eventualmente interagem, mas seguem solitários. O público acompanha a performance em uma arquibancada a $50 \mathrm{~m}$ da cena. Segundo a diretora, durante os ensaios, sua cadeira foi ficando cada vez mais distante.

No horário marcado, o público é reunido e embarca em um ônibus. Chegando ao local da peformance, caminha-se mais até a arquibancada, montada num amplo terreno vazio, irregular, que não tenha sido especialmente limpo ou capinado para a ocasião. Depois de algum tempo em silêncio, um homem surge de longe. Caminha e senta-se no chão, arrancando um pouco de mato, sem se relacionar com a plateia distante. Outras figuras vão surgindo aos poucos. De todos os lados, cruzando o campo aberto, sem expressões definidas, andando e executando ações simples, esquemáticas - cavando, carregando ferramentas, objetos. Não interagem e em geral não se reconhecem, exceto em poucas rápidas cenas, que retratam relacionamentos de passagem, sem permanência.

Um homem caiu subitamente, morto. Os outros vão até ele e o despem, levando todas as suas roupas e objetos, o abandonam nu. Mais tempo. Um homem aborda uma mulher e a violenta. Depois, ambos se afastam. Ele volta a cavar, ela se lava com um balde e um pano, depois segue. Outras ações se sucedem, no mesmo clima. Em determinado momento, entra uma mulher vestida mais formalmente, suas roupas não se identificam com aquele grupo, traz uma bolsa. Ela aborda uma e outra pessoa, e os primeiros não Ihe dão atenção. Outros a despojam de seus pertences. Passa a tornar-se parte daquele lugar, comportando-se aos poucos como os outros.

Depois de mais tempo, dois homens brigam por um pouco de madeira, um mata o outro e o joga num buraco. O primeiro será morto a pauladas por outro homem que chega. Todos vão se aproximando aos poucos, matando-se entre si e lançando os corpos no buraco. A última, a mulher que possuiu uma bolsa, atira-se também no buraco. Termina o espetáculo.

No momento dos aplausos, quando os atores saem do que imaginamos ser um buraco ou trincheira, reina certa perplexidade. O que se viu foram fatos, ações, mas desprovidos de significado e de sentido. Não são oferecidas explicações. A uma longa distância como a que nos foi imposta, não há certezas, apenas suposições.

Ao final, a companhia convida a todos para um copo de vinho, numa mesa montada próximo à saída.

Uma das mais fortes impressões do espetáculo é a noção da impossibilidade de julgamento ou de conclusão. A distância impede a empatia, uma vez que não são tentadas 
outras estratégias para estabelecê-la. Curiosamente, alguns comentários da plateia após a performance repetiram-se também numa pesquisa pela internet em blogs. Impressões como "a mulher branca, intrusa, foi alijada de seus pertences", e sobre a mesma cena "a única que não está entregue, a mulher tenta se comunicar, chamar os outros à vida"'

São imagens e sensações que se sobrepõem e completam a informação a partir de referências internas, aproximando as conclusões conforme essas identificações pessoais. Não é esse exercício, no entanto, que nos afasta da primeira discussão: a contemplação de corpos que vagam executando ações de vida e morte e, de alguma forma, identificados apenas com o lugar que ocupam. Trata-se de um lugar sem função, além daquela de permanecer enquanto possível.

Os personagens existem, movem-se em função de necessidades imediatas. Os encontros só acontecem com objetivos utilitários e geram situações limite. Esses limites, no entanto, não resultam em mudanças ou transformações. Chegam ao limite, mas não o ultrapassam. Vivem no limite, o que, de certa forma, elimina sua característica extrema. $O$ único limite real é a própria morte, já que a morte do outro passa a ser uma contingência.

O que o espetáculo oferece, afora qualquer entendimento ou busca de significado, é a experiência de reconhecer existências como aquelas; trata-se da vivência de perceber essa realidade e de observá-la à distância, sem contato efetivo, convivendo, no entanto, sob a mesma moldura - infinita, ou inexistente. A cena, de dimensões cinematográficas, não oferece delimitações entre seu espaço e o do público. Essa espacialidade constitui o que Lehmann classifica como espaço centrífugo, que dirige o olhar não para o palco, como uma perspectiva, mas o expande, criando um movimento que sempre se refere ao externo, ao ilimitado. Uma construção que favorece o afastamento, dificulta a empatia e espreita a extinção.

A plateia, inserida então no mesmo espaço, não pode retornar sozinha, pois não teve a referência do caminho. Ocupa apenas outro lugar, no mesmo contexto. Quanto aos personagens, as finalidades imediatas parecem situá-los. Vivem uma realidade simplificada, mais segura, por viver apenas o presente.

A discussão subjacente, das formas de vida que convivem nas sociedades vigentes, em estados diferentes de autonomia e de presença política, é tocada não apenas pela poética da cena, mas pela situação de fruição em que se coloca a plateia. O espectador é confrontado com a vida nua, em cena, e exposto à situação de dúvida e incapacidade de julgamento, à qual está exposto em grande parte de seu tempo, em relação aos que 
vivem de forma distinta - o morador de rua, o terrorista, o que possui bens em excesso. O espectador observa a si mesmo, percebendo essa distância ou convive com ela de forma habitual, tirando suas conclusões e aceitando um entendimento que o próprio espetáculo não oferece. Fica a cargo do indivíduo, mesmo que espontaneamente, escoIher a quão desestabilizadora de seus hábitos - ou não - poderá ser a experiência.

A temporada dos Efêmeros, em São Paulo, buscou reproduzir a experiência praticada pelo grupo em sua sede, na França, ou seja, o público é recebido pelos artistas de toda a trupe, circula pelo espaço do grande galpão, onde pode tomar um chá ou fazer uma refeição, com um cardápio que se relaciona com o espetáculo em cartaz. Convive com os camarins, montados próximos ao palco, em que pode antever maquiagem e preparação dos atores, se desejar, e conhece o trabalho do grupo pelas publicações disponíveis. Em montagens em geral longas, o tom é de receptividade e acolhimento.

No caso específico dessa montagem, o propósito do espetáculo é tratar exatamente do amor e do acolhimento. Os Efêmeros foi dirigido pela fundadora do grupo, Ariane Mnouchkine, que recebe o público todas as noites antes da performance.

O espetáculo acontece em um corredor central entre as arquibancadas, posicionadas frente a frente. As cenas se sucedem sobre plataformas com rodas, passando pelo espaço e permanecendo apenas o tempo de sua duração. Cada plataforma, no entanto, é um palco com adereços e objetos realistas, espaço para que os atores tragam personagens muito humanos, algumas vezes flertando com a máscara, ao retratar comportamentos mais arraigados, como a idosa que se acredita grávida, ou mais sutis, como o travesti que comemora seu aniversário na companhia da pequena vizinha. É um espetáculo que se propõe, conforme a definição do grupo, a falar sobre a bondade, na qual se manifesta esse sentimento, perpassando as relações e acontecimentos.

A experiência constitui um exercício de foco. O foco no presente, no papel de cada um e seu lugar naquele momento, na cena e nas histórias contadas. O público é convidado a perceber onde e com quem está, assiste e participa da construção do ritual que resultará no espetáculo do dia e conduzido, pelos encontros, informações e sensações, a manter seu foco no momento corrente. A função vai se construindo à sua frente, embora seja apenas um momento específico de uma história maior, porém é seu momento, diferente de todos os outros por isso.

As cenas cheias de detalhes, delicadas e com personagens muito peculiares, atraem o espectador como numa espiral, que o faz buscar o pequeno, o interior, sem, no entanto, poder desligar-se das grandes proporções do palco e das arquibancadas que 
mostram o público a sua frente e o mantém próximo dos demais ao seu lado, abaixo e acima. As plataformas, alternando-se, são empurradas pelos atores da companhia, que se revezam como contrarregras, também garantem que a escolha tenha que ser feita a cada momento, pois esse movimento não permite esquecer o entorno, além de remeter à passagem do tempo, que dá saltos ou evolui lentamente, no contexto específico de cada história e seu conjunto de cenas, intercaladas com outros fragmentos de histórias.

Inversamente à experiência de Braakland, essa é uma espacialidade centrípeta, que conduz a percepção ao centro e ao fundo da cena, conferindo uma dinâmica de atenção em espiral. Não é também um palco dotado de moldura, que delimita o que é externo a ele, mas que procura indicar sempre a presença do que está 'fora' da cena. Exatamente propondo a experimentação da escolha como marco do estranhamento. A interpretação e o texto conduzem à emoção, assim como objetos e a visualidade do cenário de cada plataforma. Esse jogo de identificação e estranhamento acrescenta outra dimensão da experiência, a de entender essas duas possibilidades e assumir a condução do jogo ou a postura de deixar-se conduzir.

A noção que subjaz à experiência de Os Efêmeros é a da relação com o tempo, a questão do presente e da permanência, a percepção e a discussão da fragmentação, na medida em que o detalhamento e fruição desse fragmento cria a relação com outro, que veio ou que virá, e com o qual formará uma história. Apesar da longa duração, a estética e a estrutura do espetáculo não favorecem escapes; nem para a divagação, como acontece com as longas pontuações de Robert Wilson, nem para a abreviação da sensação. Seja pelos tempos e ritmos da cena, pelo diálogo constante com o entorno, ou pela poética do texto e da interpretação, a duração é percebida sem mascaramento, porém também sem ser explorada como incômodo, mas como valorização.

Como apontado, entendemos que a espacialidade, nesse contexto, faz parte de uma rede de deslocamentos e que o espectador, nesse percurso, não tem um papel passivo, não obstante tenha ainda o papel de testemunhar, ou seja, participante de uma apresentação, uma construção em que a ação do espectador não necessita ser um operador sobre o andamento ou conteúdo da cena para que tenha um papel ativo e determinante na relação com o espetáculo. Dessa forma, é possível discutir inclusive a ideia dualista de atividade-passividade, que bem tem necessitado de uma revisão, em nosso cotidiano de indivíduos. 


\section{Bibliografia}

AGAMBEN, Giorgio. O que é o contemporâneo e outros ensaios. Chapecó: Argos, 2009.

Profanações. São Paulo: Boitempo, 2007.

FERNANDES, Silvia. Teatralidades Contemporâneas. São Paulo: Perspectiva, 2010.

FÉRAL, Josette. Encontros com Ariane Mnouchine: erguendo um monumento ao efêmero. São Paulo: Edições Sesc São Paulo/Editora Senac São Paulo, 2010.

FERRARA, Lucrécia D'Alessio. Comunicação, espaço, cultura. São Paulo: AnnaBlume, 2008.

FOUCAULT, Michel. Ditos e Escritos, Vol. I a VII. São Paulo: Forense Universitária, 1999.

GREINER, Christine. O corpo: pistas para estudos indisciplinares. São Paulo: AnnaBlume, 2005.

O corpo em crise: novas pistas e o curto-circuito das representações. São Paulo: AnnaBlume, 2010.

LEHMANN, Hans-Thies. Teatro pós-dramático. São Paulo: Cosac Naify, 2007.

MARTÍN-BARBERO, Jesús. La educacion desde la comunicacion. Bogotá: Grupo Editorial Norma, 2003.

RANCIÈRE, Jacques. O espectador emancipado. Lisboa: Orfeu Negro, 2010.

SANTOS, Boaventura de Sousa. A Gramática do tempo. São Paulo: Cortez, 2006.

SANTOS, Milton. A natureza do Espaço. São Paulo: Hucitec, 1996.

SESC São Paulo (Org.). Les Éphémères - Os Efêmeros. São Paulo: Edições SESC São Paulo, 2007.

Recebido em 05/03/2014

Aprovado em 17/04/2014

Publicado em 30/06/2014 